\title{
O PRINCÍPIO DA EFICIÊNCIA E O PODER JUDICIÁRIO
}

THE PRINCIPLE OF EFFICIENCY AND THE JUDICIARY

Heliana Coutinho Hess'

\begin{abstract}
Resumo:
O princípio da eficiência do sistema judicial foi introduzida pela reforma do sistema judicial Constitucional (EC45/04). As alterações nos tribunais superiores eficaz e tribunais de pequenas causas, informatização, procedimentos virtuais, procedimentos rápidos e meios alternativos de resolução de conflitos são instrumentos úteis para alterar de administração judicial. A eficiência da administração foi revelada como um novo paradigma da gestão judiciária.
\end{abstract}

Palavras chaves: Eficiência judicial. Gestão judicial. Tribunais. Pequenas Causas. Informatização. Racionalização. Medicação de Conflitos. Novo Paradigma de Gestão Judicial

\begin{abstract}
:
The Principle of Efficiency of the Judiciary was introduced by the Constitucional Judiciary Reform (EC45/04). The changes in effective Superiors Courts and Small Claims Court, the informatization, virtual procedures, speedy procedures and alternative means of solving conflicts are useful instruments to change de judicial administration. The efficiency of administration has been revealead as a new paradigm of the Judicial Management.
\end{abstract}

Keywords: Judicial Efficiency. Reforms of Judiciary. Courts. Small Claims Courts. Informatization. Efficient Procedures. Racionalization. New Paradigm. Judicial Management.

1. Pauta de reformas para a eficiência do judiciário

Já não é de hoje que o Poder Judiciário tem sido analisado por juristas e cientistas políticos com a preocupação constante de tecer análise sobre as reformas judiciais desde a época do Império, passando pela República até a histórica mudança da Assembléia Constituinte, que aprovou a Constituição Federal em 5 de outubro de 1998.

Embora a nossa Constituição Cidadã (nas palavras de Ulisses Guimarães) tenha avançado, ainda paira a "crise da Justiça" em nosso País. Para atenuá-la, precisamos concretizar e unificar políticas públicas para informatização com orçamento específico para a melhoria da prestação dos serviços judiciais.

Juíza de Direito. Doutora em Direito do Estado pela Faculdade de Direito da Universidade de São Paulo. Pesquisadora e Pós-Doutoranda no IFCH da UNICAMP 
A análise do poder político no Estado de Direito, do tripé do balanceamento e fiscalização entre os três poderes, que vem desde O Espírito das Leis de Montesquieu, motivou as reformas judiciais por intenso debate na Assembléia Constituinte de 1988. E daí por diante, à medida que o Estado de Direito Democrático passa por transformações político-sociais, modifica-se também o órgão, a estrutura e a instituição do Judiciário.

Nesse sentido, o cientista político, Professor Andrei Koerner da UNICAMP, já expressava que, por meio do viés de análise do contexto político na época do Império até a República, podia-se traçar a evolução da estrutura e organização do Judiciário e da cidadania em nosso país. A evolução das reformas Judiciais perpassa pela representação dos segmentos políticos dominantes das oligarquias do Império aos grupos de elite do poder político da República, em períodos históricos do Brasil, que influenciaram a formação estrutural do Poder Judiciário.'

Na conformação dos Poderes da República, a atual reforma do Poder Judiciário teve início após a promulgação da Constituição Federal de 1988. Porém, poucas foram as modificações introduzidas na Lei Maior pelos debates na arena política da Assembléia Nacional Constituinte de 1988. Pontualmente foram introduzidas as modificações com a criação e competência atribuídas ao Superior Tribunal de Justiça (art. 92, II e 104 e 105), Juizados Especiais (art.98, I e parágrafo único). Ampliação dos legitimados para propor ação de inconstitucionalidade direta, com o controle concentrado ampliado (art. 103, parágrafos $1^{\circ}$ e $3^{\circ}$ ).

Após, foram editadas Emendas Constitucionais com Modificações Pontuais que trouxeram inovações de competência do STF e STJ (EC n. 3/1993). Alterações na carreira do Judiciário, quanto à remuneração e previdência (EC n. 19/1998, EC n. 20/1998, EC n. 23/1999, EC n. 24/1999, EC 30/2000 e EC n. 41/03 e CE 47/05) e a criação de Juizados Especiais Federais (EC n. 22/1999).

KOERNER, Andrei. Judiciário e cidadania na Constituição da República Brasileira. São Paulo: HUCITEC, Departamento de Ciência Política da USP, 1998. Em introdução formulada afirma o autor: "Esse domínio de análise, que pode ser chamado de política judiciária, compreende o caráter estratégico da forma de organização judiciária na constituição do poder político e na mediação das relações sociais. Procuramos fazer, por um lado, um estudo que valorize os aspectos jurídicos da organização do Poder Judiciário, sem limitá-lo apenas à sua estrutura jurídico-formal. Por outro lado, fazemos uma análise institucional do Poder Judiciário, procurando não tomá-lo apenas nas suas relações com o sistema político em sentido estrito. $\mathrm{O}$ nosso objetivo é buscar as mediações entre o Poder Judiciário, o sistema político e a organização social. Então, com o estudo da política judiciária brasileira do Império à Primeira República, procuramos identificar as características institucionais do Poder Judiciário de modo a apresentá-las, inicialmente, como o resultado de estratégias políticas de construção institucional adotadas pelas elites políticas; em seguida, como uma forma particular de organização inserida numa estrutura de poder político; e, enfim, como um determinado tipo de mediação dos conflitos sociais, e portanto de integração da sociedade.O nosso argumento é que as continuidades na forma de organização judiciária brasileira resultaram de determinada política judiciária, cujo sentido se esclarece quando essas continuidades são contrastadas com os processos de mudança social e política, da sociedade imperial e escravista à sociedade republicana e fundada no trabalho livre". (p. 27). 
A expressiva "reforma do Judiciário" com modificações na estrutura interna e criação de instrumentos de controle externo somente se concretizou após 12 anos de longos debates e discussões iniciados com a PEC 96/1992, aprovada na Câmara dos Deputados em 2000, original do projeto apresentado pelo deputado Hélio Bicudo (PT-SP). Esta sofreu modificações com a revisão constitucional em 1993/94, à época em que o deputado Nelson Jobim (PMDB-RS), por meio de debates da "crise do Judiciário" reforçou a necessidade de mudanças estruturais e institucionais. A Comissão Especial da Câmara dos Deputados, criada em agosto de 1995, passou a analisar a PEC 96/92, com o relator Jairo Carneiro (PFL-BA); porém, não houve continuidade e foram afastados os debates.

Impulsionado por fato histórico que ocorreu em 1999, criticado por intervenções para o controle político, o senador Antonio Carlos Magalhães incentivou a reabertura dos debates e propôs uma CPI para investigar desvio de verbas públicas no Judiciário. Neste cenário, o então vice-presidente do Supremo Tribunal Federal, ministro Carlos Velloso, para amenizar a crise política entre os dois Poderes, reforçou a necessidade de modificação por emenda de reformas judiciais. ${ }^{2}$

Por longos anos, o projeto de reformar o Judiciário foi debatido, passando pelos relatores Jairo Carneiro (PFL-BA), Aloysio Nunes Ferreira (PSDB-SP), Zulaiê Cobra (PSDB-SP) e, muitas vezes, por falta de vontade política, esquecidas. Mas com o apoio da AMB e das associações dos magistrados de todo o País, foi feita a discussão dos destaques da PEC 92/96, foram aprovadas na Comissão de Constituição e Justiça e levadas a votação, conforme o processo legislativo (primeiro e segundo turno na Câmara Federal). E, finalmente apartados os destaques não aprovados no Senado, o texto final foi votado e promulgado da emenda Constitucional n. 45 de 8 de dezembro de 2004.

Nesta arena política, ocorreu a votação de 165 destaques da EC, a qual foi realizada de maneira açodada, com critérios pouco usuais, e, em certos momentos, sem amparo regimental (prevalecendo acordo de lideranças partidárias). O presidente da Casa do Senado, senador José Sarney, com o aval dos líderes partidários, extinguiu todos os interstícios previstos no Regimento Interno do Senado, entre o primeiro e o segundo turno, e em poucos minutos realizou as três sessões de discussão e votação em segundo turno da proposta, sem nem mesmo ter a redação da matéria. ${ }^{3}$

Após esta década de tramitação no Congresso Nacional, a Emenda à Constituição que trata da Reforma do Poder Judiciário foi votada e promulgada sob n. 45

SADEK, Maria Tereza (Org.) Reforma do Judiciário. São Paulo: Fundação Konrad Adenauer, 2001. p. 9-20. AMB: divulgação do texto aprovado e enviado ao Presidente, pesquisa pelo site da AMB, em novembro de 2004. 
em 8 de dezembro de 2004, data que marcou o início de mudanças no Poder Judiciário e que, a partir daí, impulsionou a modernização estrutural do Judiciário.

\section{Críticas às Paliativas reformas do judiciário}

O Poder Judiciário tem merecido destaque em todos os Estados de Direito Modernos.

As constituições modernas dos países europeus, com destaque a da Alemanha (Grundgesetz/1949), trouxeram significativas modificações para o Judiciário. Destacamse os procedimentos judiciais (como, por exemplo, a realização da execução processual por intermédio de oficiais e funcionários do serviço judicial), a competência dos juízes singulares para determinados julgamentos nas Câmaras Estaduais, a limitação de recursos por valores de alçada e por matéria mais restrita, e outras mudanças de organização da justiça. $^{4}$

As reformas são de quatro grandes ordens: a) estruturais do Judiciário informatização, que necessita ser implementada; virtualização dos procedimentos e instrumentalização dos atos judiciais em comunicação com os operadores do Direito; b) institucionais - julgamentos de repercussão geral, por decisão de recurso extraordinário de matéria constitucional, Súmulas impeditivas de recursos, súmulas vinculantes dos Tribunais de Superposição e regulamentação administrativa por decisões do Conselho Nacional da Magistratura; c) procedimentais de legislação complementar do Estatuto da Magistratura e ordinária federal para celeridade do processual, mediação e conciliação; e d) recursos humanos - mudança do operador do Direito, escolas de magistratura com cursos para aperfeiçoamento e promoção por merecimento, limitação de faculdades de Direito e exigência de experiência, e cursos de ingresso nas provas da Ordem dos Advogados do Brasil (OAB) e concursos públicos.

A pretensa reforma até o momento foi alvo de críticas por muitos juristas porque não ocasionou mudanças suficientemente significativas na estrutura da prestação de serviços judiciais a ponto de contribuir para a celeridade processual e a tão esperada distribuição de justiça.

O desembargador Celso Luiz Limongi, Presidente do Poder Judiciário Paulista (biênio 2006/2007) destaca o projeto do Banco Mundial para as reformas do Judiciário da América Latina e Caribe, seguindo o modelo técnico n 319, denominado O setor judiciário na América Latina e no Caribe - Elementos para a Reforma. Os objetivos deste instrumento visam à interpretação de leis de forma igualitária e eficiente, por meio de previsibilidade nos resultados de processos, acessibilidade às Cortes pela

4 DAV-Fórum, Justiz Reform, Zivilprocess, Berlim, 20, januar, 2000. 
população, tempo razoável de duração e processos adequados. ${ }^{5}$ Tece o Des. Celso Luiz Limongi críticas ao projeto de reforma, consoante a preocupação do Banco Mundial, expressa no documento técnico 319- O setor Judiciário na América Latina e no CaribeElementos de Reforma - porque visaria proteger os grandes conglomerados e o patrimônio econômicofinanceiro, fazendo cumprir os contratos mesmo em detrimento das empresas nacionais, sob a alegação de pacta sunt servanda e de que a lei deve ser cumprida de modo previsível e eficiente. A crítica faz referência à posição filosófica dos magistrados brasileiros que se colocam em posição contrária aos ditames de um Judiciário fechado e controlado, por interesses econômicos externos.

Não se pretende aqui polemizar sobre as motivações que pretendem um Judiciário controlado por assuntos de interesse políticos, mas sim analisar o avanço das reformas e ainda o caminho a seguir para modificações na estrutura do Judiciário e na independência de gestão administrativo-financeira, apartada do Executivo para custeio de despesas com recursos humanos e informatização. ${ }^{6}$

Falta ainda a promulgação da nova Lei Orgânica da Magistratura, em substituição a LC 35/1979, com as alterações pela LC 37/79, 54/1986 e 60/1989 para a estruturação do Poder Judiciário unificado e estruturado em âmbito nacional.

A importância de nova LOMAN, de iniciativa originária do STF, foi ressaltada pelo desembargador mineiro, Reinaldo Ximenes Carneiro, para quem a modernização administrativa e orçamentária somente poderá ser implementada com regras a serem fixadas na futura Lei Complementar da Magistratura (LOMAN) para direcionar e unificar em todos os Tribunais as reformas administrativas, de votação do órgão especial e da cúpula administrativa, bem como das regras para a escolha dos Ministros do STF e STJ. Teria também por objetivo a escolha por meio do quinto constitucional de listas sêxtuplas dos órgãos e organização de comissões especiais para direcionamento e estudos dos problemas do Judiciário, como forma de interagir positivamente com o Legislativo e Executivo.?

LIMONGE, Celso Luiz; STEFANO, Cláudia. Breves Anotações sobre a Reforma do Judiciário. In: ALMEIDA, Jorge Luiz de (Coord). A Reforma do Judiciário, uma abordagem sobre a Emenda Constitucional 45/2004. São Paulo/Campinas: Millennium, 2007. p. 14.

- O Presidente da APAMAGIS, Des. Nelson Henrique Calandra, teceu comentários sobre as dificuldades enfrentadas pelo Judiciário Paulista com o controle do orçamento e Lei de Responsabilidade Fiscal em excelente artigo na Folha de São Paulo, Informatização do Judiciário Paulista. In: Tendência e Debates. Opinião A. sábado, 1.11.08.

7 O Judiciário da Reforma sob o Jugo da LOMAN. Disponível em: <http://www.migalhas.com.br de 10/9/08>, O Des. Ximenes do TJ/MG, critica: "A Reforma do Judiciário consubstanciada na Emenda Constitucional n. 45/2004 não foi implantada em sua inteireza. Na verdade, só a parte que interessava a um de seus maiores pregoeiros foi aproveitada: a instalação do Conselho Nacional de Justiça. Tudo o mais que foi aprovado é auto aplicável e não se materializa, porque não se liberta o Judiciário da vocação autoritária e materialista"[...]. 
De nada adiantarão as mudanças estruturais do Judiciário se não acompanhadas de simplificação de procedimentos recursais e executivos, seguidos de meios alternativos de solução de conflitos ajustados para conter a demanda desenfreada de ações judiciais. Os conflitos multifacetários da sociedade globalizada exigem cada vez mais análise de questões repetitivas, principalmente quanto à matéria tributária, administrativa, previdenciária e trabalhista.

Houve importantes modificações das leis processuais, iniciadas a partir da promulgação da EC 45/04, como por exemplo, citação por correio por meio eletrônico (virtual), as penhoras de faturamento e on-line, multas aplicadas ao processo de execução, julgamentos com questões idênticas em primeiro e segundo grau, questões de repercussão geral, limitação ao recebimento de recursos, súmulas vinculantes, normatização dos procedimentos cartoriais e administrativos pelo CNJ a lei para a Tecnologia de Informática aplicada ao Processo Judicial (Lei n. 9.800/1999).

Assim, a modernização caminha a passos largos e começou com o impulso da Reforma do Judiciário, representada principalmente pela EC 45/2004 da Constituição Federal.

3. Inovações da emenda constitucional 45/2004

A EC 45/2004 abrangeu uma "grande reforma" do Poder Judiciário com inovações na estrutura organizacional e carreira do Judiciário, as quais não foram atingidas por modificações pontuais anteriores.

As modificações ao Poder Judiciário são significativas e impulsionaram as transformações que se seguiram nos tribunais a fim de melhorar a prestação jurisdicional. Porém, tais inovações não foram suficientes para amenizar o problema do acesso à justiça, principalmente na primeira instância, que é mais próxima do jurisdicionado e da aceleração e eficiência da prestação jurisdicional.

Assim, nas palavras do saudoso Ministro Domingos Franciulli Netto, ao tecer comentários à reforma do Judiciário e à legislação processual vigente, "não basta buscar o ideal idealíssimo, é necessário buscar o ideal realizável e o processo de resultados" com as modificações no sistema processual e as falhas que poderão ser trabalhadas com muito esforço pelos operadores do Direito, principalmente com a Administração Judicial. ${ }^{8}$

De outra sorte, não basta apenas a reforma institucional do Poder Judiciário, é fundamental a autonomia de gestão financeira e orçamentária para uma reforma mais ampla da administração judiciária. O Estado da pós-modernidade exige também uma

8 A Prestação Jurisdicional - o Ideal idealissimo, o ideal realizável e o processo de resultados. Campinas - SP: Millennium, 2004, p. 6-8. 
reforma de representação política do Legislativo para equilibrar-se com o Executivo centralizador e forte. ${ }^{9}$

A reforma tributária diminuirá a carga de toda uma nação para o pagamento de gastos públicos e da má distribuição de renda à educação e ao orçamento destinado pelo Governo (União e Estados) para a melhoria da máquina Judiciária. É nesse sentido que, em comentários à Reforma do Judiciário, expressa co convicção o jurista J.J. Calmon de Passos, quando aduz:

a crise é do Estado brasileiro como institucionalizado constitucionalmente em 1988. Outro convencimento é o de que será de todo inoperante qualquer tentativa de solução parcial abrangendo apenas o Judiciário, dado que sua a crise ocorre, com já afirmei reiteradamente, em conseqüência de uma infecção externa (...) ignorar (ou ocultar) a maioria dos juristas a força determinante do econômico e do político sobre o direito, o que necessariamente significará ingenuidade, omissão grave ou perversidade ideológica de quem assim procede. $^{10}$

Neste sentido, o Estado de Direito na sua forma atual, com todas as interferências do sistema econômico (globalizado) e político sistematizado na CF/88, sofre em não poder realizar o ideal de justiça distributiva e social, como pretendem os operadores do Direito, em suas esferas de atuação.

Neste contexto, de grande volatilidade de informações, de transformações de paradigmas econômicos e de insegurança nas relações sociais, o Direito estável nos códigos e leis acaba por se tornar ultrapassado, logo depois de sua promulgação e vigência.

Assim, não foi diferente com a reforma pretendida ao Judiciário, que também na visão crítica de J. J. Calmon de Passos "manteve nosso catálogo telefônico constitucional" "l pois aumentou o capítulo do Poder Judiciário quando deveria diminuí-lo para a efetiva prestação jurisdicional.

Entretanto, foram necessárias mudanças institucionais para alavancar muitas outras modificações na estrutura do nosso sistema jurídico de operatividade do Direito, fincado sob as bases do sistema romano-germânico de legislação codificada e de origem do Poder Legislativo.

Este início propiciado pela EC $45 / 04$ deverá ser ampliado passo a passo, com esforço em conjunto da sociedade, mormente da troca de idéias entre juristas, políticos e

9 CLÉVE, Clémerson Merlin. Breves comentários sobre os 20 anos da Constituição Federal. Disponível em: $<$ http://www.migalhas.com.br>. Acesso em: 6 out. 08.

10 PASSOS, J. J. Calmon de. Reforma do Poder Judiciário. Revista Brasileira de Ciência Criminais, v. 16, n. 71, mar./abr.2008, p. 345.

$11 \quad$ Id. Ibid., p. 353. 
economistas, para um novo Poder Judiciário, com prestação jurisdicional sincronizada com o bem estar social num Estado de Direito Democrático.

\section{Princípio da eficiência e celeridade processual ${ }^{12}$}

O maior problema da Justiça brasileira tem sido atribuído ao descompasso entre o tempo do processo com a finalização da execução e satisfação do direito exigido e o tempo do mundo moderno globalizado.

O paradigma da justiça deve ser modificado para deixar de atuar somente em tempo pretérito, em restauração do direito lesado, a fim de resgatar o direito presente, não somente com o auxílio da informática, bem como de meios alternativos de solução de conflitos em ação conjunta com o Judiciário.

A modulação do tempo presente deve pautar-se pelo brocardo: tempus fugit, carpe diem!

Por isso, preocupou-se o constituinte em introduzir na reforma do Judiciário o direito fundamental do "tempo do processo" ou seja, o processo em tempo razoável e instrumentos para realizar o bem da vida ainda em tempo de satisfazer o jurisdicionado em seu sentimento de reparação de bem lesado ou na garantia de direito, para cumprir a justiça distributiva humana.

Assim, é a norma objetivo do Princípio da Celeridade Processual, in verbis:

Art. $5^{\circ}$

$[\ldots .$.

LXXVIII: a todos, no âmbito judicial e administrativo, são assegurados a razoável duração do processo e os meios que garantam a celeridade de sua tramitação.

A "razoável duração do processo" e "meios que garantam a celeridade de tramitação", são conceitos abertos e ainda indeterminados. A norma constitucional é abstrata e não auto-aplicável, conforme o ensinamento de José Afonso da Silva. ${ }^{13}$

O Brasil aderiu ao Pacto de São José da Costa Rica (Decreto n. 678/1992) e garante o direito de todas as pessoas de serem ouvidas, com as garantias processuais de defesa e dentro de um prazo razoável do procedimento. O processo de duração razoável

12 Cf. BENUCCI, Renato Luís. A tecnologia aplicada ao processo judicial. Campinas, SP: Millenium, 2007. p 25 ss; COSTA, Marcos da; MARCACINI, Augusto Tavares Rosa. Direito em Bits. São Paulo: Fiúza, 2004. ALMEIDA, Jorge Luiz de. Emenda constitucional n. 45/04 e responsabilidade. p. 1-28; OLIVEIRA, Luiz. Flávio de. A razoável duração processo na perspectiva dos direitos humanos. p. 89-104; DE PIERI, Sueli Aparecida. Princípio da celeridade processual; Duração razoável do processo e hierarquia da normas de tratados internacionais de direitos humanos: Instituidos pela Emenda Constitucional n. 45, p. 105-131. In: A Reforma Do Poder Judiciário. Campinas, SP: Millennium, 2006.

13 SILVA, José Afonso da. Curso de direito constitucional positivo. 5. ed. São Paulo: Revista dos Tribunais, 1989. 
está ligado à distribuição de justiça e à garantia de direitos e da concretização no plano de fato, de obtenção do bem da vida para o jurisdicionado.

Este princípio revela necessidade de serem ajustadas condutas procedimentais adequadas e aperfeiçoamento da legislação processual e dos instrumentos de informatização dos tribunais.

Neste sentido, a Constituição remete ao art. 93, XII, XIII, XIV e XV da CF que dispõe, respectivamente sobre a prestação jurisdicional ininterrupta, a vedação das férias coletivas e o funcionamento de plantões judiciais em dias sem expediente normal, a proporcionalidade de juízes/cidadãos nas jurisdições territoriais, delegação aos servidores de prática de atos não decisórios e a distribuição imediata de processos em todos os graus de jurisdição.

Ao comentar este princípio, o desembargador aposentado Jorge Luiz de Almeida, esclarece: "O conceito de razoável duração do processo não fixa medida temporal. É comando a ser aplicado em atenção às peculiaridades do processo. Não é restritivo do direito à prova. Veda, sim, tempo vago para soluções sobre o direito em razão de formalismos, de delongas para a movimentação dos autos. É reprovação do chamado "sono do processo (Tarzia)" 14

Para implementar ainda, afigura-se a ligação com o princípio da eficiência da administração pública, insculpido no art. 37 caput, bem como o princípio da economicidade, ${ }^{15}$ na fiscalização dos poderes públicos, descrito no art. 70 caput, ambos da CF/88.

Note-se que o inciso LXXVIII foi inserido estrategicamente no art. $5^{\circ} \mathrm{da}$ nossa Carta Maior, como princípio fundamental e subjetivo de cada cidadão em exigir o aperfeiçoamento e a prática desta norma basilar.

A norma constitucional é direcionada para o Legislativo, na elaboração de leis que imprimam a celeridade processual, assim como para o Executivo, na aceitação e aumento de orçamento anual adequado e suficiente para atender as reivindicações de verbas de despesas com material e recursos humanos do Poder Judiciário, a fim de aparelhálo para que possa atender a demanda crescente em razão do princípio constitucional de inafastabilidade do controle jurisdicional, ou seja, do direito ao acesso à Justiça (inc. $\mathrm{XXXV}$, art. $5^{\circ}$ : da $\mathrm{CF}$ ).

14 ALMEIDA, Jorge Luiz (Coord.). Emenda constitucional n. 45/04 e responsabilidade. In: A Reforma do Poder Judiciário. Campinas-SP: Millennium, 2006. p. 3.

15 DELGADO, José Augusto. Reforma do Poder Judiciário, art. $5^{\circ}$, LXXVIII, da CF. In: WAMBIER, Teresa Arruda Alvim et al (Coord.). Reforma do Judiciário: primeiros ensaios críticos sobre a EC n. 45/2004. São Paulo: Revista dos Tribunais, 2005. p. 356. Acrescenta ainda que é um postulado, um princípio, uma garantia constitucional que tem aplicação imediata e que é impulsionado pelo princípio da razoabilidade, que se encontra inserido no contexto de idéias democráticas que inspiraram o constituinte de 1988. 
A prática de premissas do princípio da celeridade e da razoável duração do processo já vem fundada na instrumentalidade de formas processuais e das medidas cautelares e antecipatórias. ${ }^{16}$ A razoabilidade da duração do processo depende também da perspicácia de juiz proativo na condução do processo, com a finalidade de buscar meios para facilitar o acesso das partes, da flexibilidade na aceitação de provas, mormente em processos com direitos difusos e coletivos, na maximização da comunicação dos atos processuais por meios eletrônicos com as partes e seus advogados, na busca pela inversão do ônus da prova (art. $6^{\circ}$ VIII, CDC), desconsideração da personalidade jurídica, na aceitação da penhora on-line, na aplicação de multas diárias para o caso de descumprimento da decisão, ou abuso processual e má-fé. Enfim, como ressalta José Renato Nalini, a melhoria da prestação jurisdicional "depende de um juiz ajustado ao tempo do processo, comprometido com realização do justo, apesar das deficiências materiais e a carga irracional de trabalho" ${ }^{17}$ De outra sorte, o princípio do "tempo razoável do processo" não prescinde de assegurar aos litigantes os prazos necessários para o desenvolvimento do due processo of Law, que se baseia no Princípio da Segurança Jurídica, do amadurecimento e assertividade de uma decisão Judicial no Estado de Direito.

Pode-se até pensar, como reflete Márcia Fernandes Bezerra sobre as consequências da responsabilidade do Estado pela demora dos procedimentos cartoriais, dos serventuários da justiça, dos auxiliares e do próprio juiz, na condução dos autos, conforme o art. $37, \S 6^{\circ}$ da CF. ${ }^{18}$

É importante ressaltar que foram implementadas reformas processuais visando à concretização do princípio da razoável duração do processo, como as modificações processuais no âmbito civil e penal. Ainda há a observância dos tratados internacionais, nos quais o Brasil é aderente para a concretização dos Direitos Humanos e o cumprimento de decisões emanadas do Tribunal Penal Internacional.

Porém, em que pesem as reformas processuais, o tempo do processo não corresponde ao tempo do mundo econômico e virtual contemporâneo, em meio a instabilidade econômica e a volatividade de capital que desestabiliza os contratos, alterando de forma virtual a (in)formação da sociedade contemporânea.

Assim, há que se indagar juntamente com o pensamento de José Renato Nalini, se o princípio da celeridade processual "seria mais um preceito programático.

16 DINAMARCO, Cândido Rangel. Manual de direito processual civil. 5. ed. São Paulo: Revista dos Tribunais. p. 72 .

17 NALINI, José Renato. A revolução da toga. São Paulo: Millennium, 2008. p. 29

18 Duração do processo e responsabilidade do Estado. In: A Reforma do Judiciário... cit., p. 472. A análise é complementada por princípios da legalidade, isonomia e da teoria do risco administrativo pela falta de prestação adequado do serviço público, pelo Estado-Juiz, quando comprovado a lesão injusta à esfera moral ou patrimonial do individuo (p. 476-477). 
Ou é norma constitucional que reclama efetividade e pode ser invocada por qualquer prejudicado, independente de ter ou não razão em seu pleito judicial?"'।9

\subsection{Modificações na legislação processual}

Algumas modificações processuais já foram realizadas para a simplificação e aceleração do procedimento, como a citação por correio (Lei n. 8.710/93) a liquidação da sentença, com apresentação de planilha de cálculos atualizados pela parte (Lei $\mathrm{n}$. 8.898/1994). Alterações dos recursos de embargos de declaração, embargos infringentes, apelação, agravo e os recursos direcionados aos tribunais superiores e nos recursos (Lei n. 8.950/93).

Importantes modificações foram feitas por meio da Lei n. 10.352/01, com novas mudanças aos recursos, assinalando, desde já a criação da jurisprudência ou súmula impeditiva de recurso. A Lei n. 10.358/01 modificou o processo de conhecimento consolidando os provimentos mandamentais de natureza antecipatória ou final.

Já nos anos de 2006 e 2007, foram realizadas modificações importantes do processo de execução, competência, antecipação de tutela, julgamento antecipado da lide, súmulas impeditivas de recursos (Leis ns. 10.444/05, 11.382/06, 11.417/06, 11.318/06, $11.419 / 06$ e $11.441 / 07)$

Importante avanço traz a Lei n. 11.672/08, com a introdução do art. 543-C ao Código de Processo Civil, para minimizar o julgamento de milhares de recursos repetitivos nos Tribunais. Ao analisar o fundamento da controvérsia de questão de direito idêntica, cabe ao presidente do Tribunal de origem admitir um ou mais recursos representativos da controvérsia e encaminhá-los ao Superior Tribunal, com a suspensão dos demais recursos nos processos em curso, até o pronunciamento e decisão a ser aplicada no caso, não sendo recebido o recurso em caso idêntico, já julgado. A Resolução n. 8 do STJ, de 7 de agosto de 2008, regulamentou esta matéria. ${ }^{20}$

\subsection{Informatização judicial}

A informatização dos procedimentos, ainda que seja em prazo de mais de 10 anos, previsto para concretização em âmbito nacional, conforme informou o $\mathrm{CNJ},{ }^{21}$ não prescinde de atualização dos processos por meio de informatização e da virtualização das citações e intimações dos advogados por meio de correio eletrônico. Exemplo disso

\footnotetext{
19 NALINI, José Renato. A revolução da toga. São Paulo: Millennium, 2008. p. 177.

20 LAGE, Ricardo Kalil. O sonho da justiça Célere. Disponível em: <http://ww.migalhas.com.br>. Acesso em: 22 set. 2008.

21 "Justiça Informatizada só daqui a 10 anos, admite CNJ". O Estado de São Paulo, São Paulo, Caderno A, de $15 / 9 / 08$
} 
é a recente Lei n. 11.280/06 permitiu a intimação dos advogados por meio do correio eletrônico de publicação nos processos do Juizado Especial Cível Federal.

A digitalização dos autos, conforme narra Renato Benucci, é positiva porque substitui a profusão de papeis, que custam tempo e dinheiro para o manuseio dos serventuários, mas deve ser feita de modo gradual para novos processos, com registros fonográficos de audiências, eliminando aos poucos a burocracia de juntada e carimbos. ${ }^{22}$ Por outro lado, sem o acompanhamento preciso de recursos humanos especializados, treinamento dos serventuários para compreensão e agilização do processo eletrônico, precária seria a substituição do papel pela virtualização dos autos. A mudança total deste paradigma requer confiança no procedimento virtual e nos operadores do sistema, para prover meios que assegurem o controle de dados, sob pena de causar insegurança operacional.

Neste sentido, Marcos da Costa argumenta a dificuldade da conferência do documento eletrônico, com formas diversas de petições em "original", com as assinaturas dos advogados e das partes, não sendo possível dispensar o documento em papel, se houver necessidade de conferência, por exemplo, por falsidade material ou divergência de conteúdo. ${ }^{23}$

Na era do Direito Digital, como afirma Patricia Peck Pinheiro: ${ }^{24}$

$\mathrm{O}$ avanço tecnológico na comunicação sempre perseguiu o objetivo de criar uma Aldeia Global, permitindo que todas as pessoas do mundo pudessem ter acesso a um fato de modo simultâneo[...]. Os programas de home-brokers já são uma realidade. Seguindo a necessidade de corte de gastos e controles maiores sobre as filiais, as empresas passam a investir em redes de comunicação interna, conectando todas as operações mundiais. Nesse estágio, os executivos experimentam plenamente as facilidades da comunicação rápida, economizando papel, pulsos telefônicos, viagens e tempo.

A gestão eficiente do Judiciário passa por essa virtualização de processo e de expedientes cartórios, com a máxima celeridade, mas com cuidado para manter o mínimo de segurança no resguardo de back up de dados, porque os processos traduzem a dinâmica da vida de cada jurisdicionado.

Esse alavanca tecnológica tem sido perseguida pela CNJ com políticas de gestão e informatização dos procedimentos e comunicação cartórios, pelo Tribunais do Trabalho, com o cumprimento de redes entre as Varas e Tribunais, nos Juizados Especiais de Execução Fiscal Federal nos tribunais federais, como informam os boletins diários

22 BENUCCI, Renato. op. cit. p. 88. A tecnologia aplicada ao processo judicial. Aduz as técnicas criptografadas com conteúdo da mensagem permite o controle por meio de chaves públicas para a segurança do processo.

23 COSTA, Marcos da. Direito em bits. cit., p. 17

24 PINHEIRO, Patricia Peck. Direito digital. 3.ed. São Paulo: Saraiva, 2009. p. 21. 
"Canal da Estratégia do Judiciário" criado pelo do CNJ para divulgar notícias sobre gestão administrativa dos Tribunais. ${ }^{25}$

Muitas serão as questões quando efetivamente puder ser regulamentada a Lei n. 11.419 de 19 de dezembro de 2006, que disciplina a informatização dos processos judicial e altera dispositivos do CPC. ${ }^{26}$

\subsection{Súmulas vinculantes e obstativas de recursos repetitivos}

Após a promulgação da Emenda Constitucional, o STF poderá (art. 103-A), de ofício ou por provocação, mediante decisão de dois terços de seus membros, aprovar súmula com efeito vinculante em relação aos demais órgãos do PJ e a administração pública direta e indireta em todas as esferas. Terão (art. 102, $\S 2^{\circ}$ ) efeitos vinculantes as decisões do Supremo nas ações diretas de inconstitucionalidade e nas ações declaratórias de lei ou ato normativo federal, atingindo a administração pública direta e indireta em todas as esferas.

A introdução no art. 103-A da súmula vinculante ou decisão de efeito vinculante para todos os órgãos do Poder Judiciário e administração direta e indireta causou efetivamente uma revolução em nosso meio jurídico.

Hoje existe a possibilidade de serem sumuladas decisões para obstar o recebimento de recursos, em casos semelhantes por relevância da matéria, por meio de decisões emanadas do STJ e do TSE, com restrição e limitação do conhecimento de recursos.

25 Cf. O sitio virtual diário: <http://www.cnj.jus.br/estrategia/index >.

26 Unidades que atualmente operam processos digitais com o SAJ (Sistema de Informatização Judicial): site do SAJ. http://www. SAJ. Org. br.:TJSC • Unidade Judiciária Avançada de Cooperação: processos de família e juizado especial, em funcionamento na faculdade Cesusc. • Unidade Regional de Execução Fiscal de Lages: este projeto integra a Secretaria da Fazenda, Procuradoria Geral e Tribunal de Justiça do Estado de Santa Catarina. - Vara de Execução Fiscal Municipal de Florianópolis: integra Secretaria da Receita, Procuradoria Geral do Município de Florianópolis e Tribunal de Justiça de Santa Catarina. TJSP - Expressinho Digital: Juizado Especial em funcionamento na estação de metrô São Bento. Essa unidade recebe reclamações contra as empresas Eletropaulo, Embratel, Sabesp, Telefônica e Unibanco, que mantêm parceria com o Tribunal no projeto. - Fórum Nossa Senhora do Ó: nesta unidade da capital paulista o SAJ gere de forma totalmente eletrônica os processos de 3 varas cíveis e 2 varas família. Essa é a primeira experiência no país em que processos cíveis de rito ordinário tramitam em ambiente $100 \%$ digital. TJAM - Varas de Família: $5^{\mathrm{a}}, 8^{\mathrm{a}}, 9^{\mathrm{a}}$, $10^{\mathrm{a}}$ e o núcleo de conciliação. Juizados Cíveis: $1^{\circ}, 2^{\circ}, 3^{\circ}, 5^{\circ}, 7^{\circ}, 9^{\circ}, 11^{\circ}, 12^{\circ}$ e $13^{\circ}$. Juizados Criminais: $13^{\circ}, 15^{\circ}, 17^{\circ}$ e $19^{\circ}$ Para os meses de agosto e setembro deste ano está programado o início de operação do processo eletrônico nas varas de Execução Criminal, Entorpecentes, Medidas e Penas Alternativas, e no restante das varas de família e juizados especiais da Capital. TJMS - Além de sediar o primeiro juizado especial das justiças estaduais com processos totalmente digitais $\left(10^{\mathrm{a}}\right.$ Vara dos Juizados Especiais Cíveis e Criminais), o estado opera nesta nova metodologia a $5^{a}$ e $11^{a}$ Varas dos Juizados Especiais. TJAL • Execução Fiscal Estadual e Municipal: Integra a Procuradoria Geral do Estado, Procuradoria Geral do Município de Maceió e Varas de Execução Fiscal Estadual e Municipal. Até setembro de 2007 todos os processos dessas unidades tramitarão sem papel. 
A EC 3/1993 tratou também pela primeira vez do efeito vinculante das decisões de mérito proferidas pelo STF em declaração da constitucionalidade de lei ou ato normativo federal (ADC) com o cumprimento para todos os órgãos do Poder Judiciário e do Poder Executivo ( $\$ 2^{\circ}$. art. 102).

Ampliou-se a legitimidade para a propositura das ADC para o Presidente da República, Mesa do Senado Federal, Mesa da Câmara dos Deputados ou pelo ProcuradorGeral da República ( $\$ 4^{\circ}$ do art. 103). Esta EC 19/98 introduziu modificações nos vencimentos, com a criação de subsídio para os membros do Poder Judiciário.

É certo que a súmula de efeito vinculante veio para enfrentar um dos grandes problemas de repetição de processos e da lentidão de julgamento sobre temas envolvendo os Entes do Estado, como tributários, administrativos, previdenciários, constitucionais e civis, entre outros.

A demora no julgamento de processos, cujos temas são repetitivos somada à procrastinação por interposição de recursos protelatórios ordinários e extraordinários, principalmente pelos Entes da Federação, aos Tribunais de Superposição (STF e STJ) inviabiliza a eficiente prestação jurisdicional (art. 5, LXVIII da CF).

Assim, a aceitação da obrigatoriedade de vinculação das decisões emitidas pela Corte Constitucional e dos Tribunais Superiores por meio de súmulas vinculantes é hoje a mais rápida via de pacificação da jurisprudência nacional. Além disso, esta racionalização dos julgamentos tende a modificar a negativa imagem de serem os juízes de primeiro grau e tribunais inferiores meros "ritos de passagem" dos recursos encaminhados para os Tribunais de Superposição (STF, STJ, TST e TSM). A execução da decisão depende para concretização efetiva do trânsito em julgado da sentença, sem mais possibilidade de interposição de recursos.

Evita-se o processamento e o custo financeiro de inúmeros processos que se multiplicam para discutir uma matéria sumulada e controla-se, via inversa, a administração pública, que se beneficia desta lentidão processual e dos inúmeros recursos para protelar o pagamento de precatórios judiciais (art. $100 \mathrm{CF}$ ).

Os recursos da administração pública serão controlados por meio de súmulas e de limitação de recursos por meio de repercussão geral da matéria já analisada pelos Tribunais Superiores. ${ }^{27}$

Desafio, entretanto, é formalizar o procedimento para atualizar a matéria, que vem sendo sumulada pelo Supremo Tribunal Federal por simplificado procedimento de revisão da decisão analisada e sumulada, diante de casos concretos. Maior ainda é o desafio do cumprimento pelos juízes e tribunais inferiores da decisão sumulada, com a

27 LAMY, Eduardo de Avelar. Súmula vinculante um desafio. Revista de Processo, São Paulo, n. 120, fev. 2005. p. 129 
interpretação, conforme a Constituição, nos termos restritos, conforme ressalta Gilmar Mendes. ${ }^{28}$

Já foram publicadas até a finalização deste trabalho 13 súmulas vinculantes ${ }^{29}$ pelo STF, dentre as quais algumas têm gerado polêmica porque não se referem a temas de importância para controlar atos da administração pública e são muito vagas e imprecisas, como por exemplo, a Súmula n. 11, que ser refere ao uso de algemas para os indiciados e réus, em casos excepcionais justificados pela periculosidade do agente.

Na mesma lógica de racionalização do processo estão as súmulas obstativas de recebimento de recursos, que também se transformam em instrumentos de agilização de julgamento do processo em primeira instância, com a decisão já analisada por repercussão geral e repetidas vezes pelos STJ e em matéria trabalhista pelo TRT.

Quanto à "súmula impeditiva de recurso" introduzida pela Lei n. $11.276 / 2006$, foi incluído na mesma o parágrafo $1^{\circ}$ do art. 518 , que impede o recebimento do recurso pelo juiz, conforme Súmula editada pelo Superior Tribunal de Justiça ou do Supremo Tribunal Federal. Neste sentido, analisa Alexia Rodrigues Brotto em texto apresentado sobre a nova proposta do impedimento de recursos protelatórios sobre temas já debatidos:

O Parecer da Comissão de Constituição, Justiça e Cidadania do Senado ressaltou, à época, que tal alteração legislativa objetivava solucionar o problema decorrente da interposição excessiva e repetitiva do recurso de apelação em face de decisões em conformidade com o entendimento pacificado dos tribunais superiores, principalmente no sentido de impor uma barreira às benesses oriundas do efeito suspensivo atribuído à Apelação. Relatou o Senador inexistir, por parte do art. $518, \S 1^{\circ}$, qualquer afronta à garantia processual dos jurisdicionados, e sim fortalecer o fortalecimento de seus privilégios, na medida em que criou um obstáculo significativo para aqueles que se servem do Judiciário com o único intuito de adiar o cumprimento de seus deveres e obrigações. ${ }^{30}$

Por fim, cabe ainda a questão da "repercussão geral de matéria" a ser analisada pelo STF para a melhor racionalização do tema e para a suspensão do recebimento de recursos em segundo grau pelos Tribunais, aguardando-se a análise da questão sub judice

28 MENDES, Gilmar. Arguição de constitucionalidade... cit., p. 121.

29 As Súmulas vinculantes aprovadas pelo Supremo são publicadas no DJE e podem ser conferidas na consulta ao site do STF.

30 BROTTO, Alexia Rodrigues. O princípio do acesso à justiça e as súmulas no sistema recursal brasileiro. Disponível em: $<\mathrm{http}: / /$ www.art. asp?idartigo-86>. 
no Supremo Tribunal Federal, para ser aplicada a todos os processos com idêntico objeto da demanda. ${ }^{31}$

Todos os instrumentos que promovam a racionalização do julgamento de recursos procrastinatórios, por meio de súmulas vinculantes, impeditivas e de repercussão geral, proporcionarão ao Judiciário a diminuição de despesas e melhor racionalização de serviços, principalmente quanto às matérias tributária, administrativa e previdenciária, constitucional, que envolvem os Entes Públicos.

\section{5. Órgãos do poder judiciário e o ideal da eficiência}

Os órgãos que compõem o Poder Judiciário Nacional estão elencados no art. 92, caput, da CF/88.

O Supremo Tribunal Federal, o Superior Tribunal de Justiça e Tribunais Superiores Trabalhista, Militar e Eleitoral, bem como o Conselho Nacional de Justiça, com sede em Brasília/DF tem jurisdição nacional (parágrafos $1^{\circ}$ e $2^{\circ}$ da $\mathrm{CF}$ ).

Inovação trazida foi a inserção, como órgão da Justiça no art. 92, inciso I-A, o Conselho Nacional de Justiça, permanecendo a estrutura dos demais órgãos de Tribunais e Juízes nos Estados.

Porém, temos na prática dois Tribunais de Superposição, o STF e o STJ, os quais tem competência para o julgamento de questões constitucionais e federais, advindas dos demais tribunais Regionais e Estaduais.

\subsection{Supremo Tribunal Federal é hoje corte constitucional}

Corte Constitucional por excelência, tem o dever precípuo de guarda e defesa da Constituição por controle concentrado da constitucionalidade.

Porém, na qualidade de Corte de Superposição Constitucional, como na Alemanha e nos Estados Unidos, esta que atua por meio do judicial review, com base em precedentes, deveria ter a sua função restrita a julgamento concentrado da constitucionalidade das Leis, deixando para as demais Cortes Superiores Especializadas a análise de recursos ordinários e de repercussão geral, com efeitos vinculativos de impedimento de recursos à Corte Constitucional.

31 O STF reconheceu a ocorrência de repercussão geral em três assuntos trazidos à Corte em Recursos Extraordinários nos últimos dias. $\mathrm{s}$ casos a serem julgados futuramente pelos ministros são de responsabilidade civil de empresas privadas no serviço público; de antecedentes penais em casos nos quais não há condenação definitiva; e de conflito de competência entre juizado especial federal e juízo federal. Esse primeiro julgamento de admissibilidade seleciona os casos nos quais o resultado do julgamento ultrapassa o interesse das partes e ganha relevância social, econômica, política ou jurídica. 
Nesta esteira, critica José Renato Nalini: "Todavia, a existência de uma constelação de tribunais, sem um órgão de planejamento ou coordenador das superiores política judiciais, ausente um plano nacional para o Poder Judiciário [...] Pode-se afirmar serem quatro instâncias postas a vencer por quem pretenda ver sua controvérsia definitivamente apreciada pela justiça: primeiro, o primeiro grau, como juiz local; o tribunal local; o Superior Tribunal de Justiça, cuja vocação de corte de cassação foi na verdade substituída por aquela de uma terceira instância ordinária; e, finalmente, o Supremo Tribunal Federal. ${ }^{32}$

A competência do STF, no entanto, é originariamente, de Corte Constitucional, seguindo o modelo alemão, ${ }^{33}$ por meio de controle concentrado e abstrato de normas constitucionais, principalmente por meio da ação direta de inconstitucionalidade (ADIn), e da ação direta de constitucionalidade (ADC), esta introdução pela EC n. 3 de 17 de março de $1993 .{ }^{34}$ Ambas foram regulamentadas pela Lei n. 9.868/99, que trata da admissibilidade e do procedimento.

Ressalta o presidente do Supremo Tribunal Federal, Gilmar Ferreira Mendes, sobre as ações diretas e respectiva lei de regência, que não se exaure na legislação a disciplina e regras para a propositura da ADIn e ADC, como controle concentrado e abstrato, mas que deve ser abrangida a matéria tratada e a legitimidade ativa, conforme o entendimento da jurisprudência do Supremo Tribunal Federal. ${ }^{35}$

Introduzida também a importante inovação sobre a arguição de descumprimento de preceito fundamental (ADPF), que pode ser arguida por meio de incidente de inconstitucionalidade em processo, por meio de recurso extraordinário, para suspender o julgamento dos autos, até que o STF se pronuncie sobre a controvérsia constitucional. Esta compreende atualmente a tendência de concentração do controle constitucional na Corte Suprema, com o pronunciamento de normas inconstitucionais federal, estadual e até municipal.

Para a regulamentação da ADPF foi publicada a Lei n. 9.882 de 2.12.1999, para regulamentar o processo e julgamento quando invocada por meio incidental em processo. Esta lei sofreu muitas críticas pela forma aberta e geral, concebendo critérios de ampliação de competência do STF para análise do "preceito fundamental" Aplica-se

NALINI, José Renato. A rebelião da toga. 2. ed. Campinas - SP: Millennium, 2008. p. 11.

Cf. MENDES, Gilmar Ferreira. Jurisdição constitucional. 5. ed. São Paulo: Saraiva, 2005. p. 3-47.

${ }^{3}$ As modificações quanto à competência do Supremo Tribunal Federal para apreciar ação direta de inconstitucionalidade de lei ou ato normativo federal ou estadual (ADIN) e ação declaratória de constitucionalidade de Lei ou ato normativo federal (ADC) (letra "a", inciso I, do art. 102), com a arguição de descumprimento de preceito fundamental $\left(\mathrm{ADPF}, \S 1^{\circ}\right)$ pelo $\mathrm{STF}$, remetendo-a a lei para a egulamentação do processo de julgamento da arguição de preceito fundamental (ADPF). ld. Ibid., p. 24।

35 Id. Ibid., p. 241. 
também o princípio da subsidiaridade do controle difuso, para a discussão por outras ações judiciais, as quais por meio de recursos chegam diariamente à Corte Suprema. ${ }^{36}$

A partir do julgamento do STF das ADINS e ADC, principalmente em matérias com arguição de preceito fundamental, será possível formar a jurisprudência de casos, como precedentes. Exemplo foi o julgamento da ADPF n. 54, caso do aborto de feto anencefálico, para em sede de liminar reconhecer o sobrestamento dos processos não julgados em definitivo e conceder o direito à gestante de submeter-se à cirurgia de abortamento, quando houvesse risco de vida para esta e para o feto. ${ }^{37}$

\subsection{Superior Tribunal de Justiça é corte informatizada}

Superior Tribunal de Justiça foi inserido na $\mathrm{CF} / 88$, como tribunal de Superposição, com competência ordinária de leis federais e estaduais, para desafogar o volume de demandas, por recursos ordinários, extraordinários e ações de inconstitucionalidade e constitucionalidade de competência do STF.

A competência para o julgamento e interpretação da lei federal, para todos os tribunais inferiores à época, foi muito elogiada para a uniformização de jurisprudência das leis federais.

Porém, o STJ já está assoberbado de processos e só por critérios de súmulas de jurisprudência com efeito vinculante poderá o STJ unificar a jurisprudência dos Tribunais Estaduais e Federais do País.

A importante modernização do STJ ocorreu com a gestão do Presidente Ministro Cesar Asfor Rocha, que ganhou o Premio Innovare 2009 "Justiça na Era Virtual", pela eficiente digitalização e informatização dos processos no STJ, facilitando o cumprimento do preceito da celeridade e eficácia do processo. ${ }^{38}$

36 VELLOSO, Carlos Mário. Arguição de descumprimento de preceito fundamental Lei n. 9.882 de 3.12.99. Revista de Diálogo Juridico, n. 12, mar. 2002, extraída do site http://www.dp.direitopublico.com.br. em 15.9.08. O Ministro Carlos Velloso afirma sobre o princípio da subsidiariedade: "Praticamente, sempre existirá, no controle concentrado ou difuso, a possibilidade de utilização de ação ou recurso a fim de sanar lesão a preceito constitucional fundamental. Então, se o Supremo Tribunal Federal der interpretação literal, rigorosa, ao $\S 1^{\circ}$ do art. $4^{\circ}$ da Lei $9.882 / 99$, a arguição será, tal qual está ocorrendo com o mandado de injunção, posta de lado. De outro lado, o Supremo Tribunal Federal, na construção da doutrina dessa arguição, deverá proceder com cautela, sob pena de consagrar, por exemplo, a ação direta de inconstitucionalidade de ato normativo municipal em face da Constituição Federal, inclusive dos atos anteriores a esta. $\mathrm{E}$ isto o constituinte não quis, nem seria suportável pelo Supremo Tribunal, dado que temos mais de cinco mil municípios.

37 MENDES, Gilmar Ferreira. Arguição de descumprimento de preceito fundamental, comentários à Lei 9.882/99. São Paulo: Saraiva, 2007. p. 20. O Ministro faz análise com bastante fundamentação e críticas à Lei 9.882/99, com quadro comparativo de votação na Câmara Federal, legitimidade e sobre o efeito vinculante das decisões do STF.

$38<\mathrm{http}: / / \mathrm{www}$.premioinnovare.com.br/ultimas/vi-premio-innovare-anuncia-vencedores-de-2009>. Acesso em: 8 jun. 2010 


\subsection{O papel de gestor do Conselho Nacional de Justiça}

O CNJ (art. 92) passa a ser órgão do Poder Judiciário, mas de natureza exclusivamente administrativa (não jurisdicional). Este é composto por quinze membros, ${ }^{39}$ os quais decidem sobre questões de ordem administrativa e planejamento orçamentário do Judiciário Nacional.

$\mathrm{O} \mathrm{CNJ}$ tem atribuições de zelar pela legalidade dos atos administrativos dos magistrados, podendo desconstituí-los ou revê-los; receber e conhecer de reclamações contra membro ou órgão do Poder Judiciário, inclusive contra os serviços auxiliares, serventias e órgãos prestadores de serviços notariais e de registro; avocar processo disciplinar, podendo determinar a remoção, a disponibilidade ou a aposentadoria.

Porém, o CNJ não terá competência para determinar a perda do cargo, que somente é decidida por quorum qualificado do órgão especial da cada Tribunal.

Desde o início dos debates no Congresso Nacional, a criação do CNJ é polêmica porque cercearia a liberdade de julgamento dos juízes e desembargadores, por meio de controle externo dos tribunais. Discutia-se por meio de ADIn (n. 3.363-DF) ajuizada pele AMB a controvérsia sobre a "quebra" do princípio da separação dos poderes, conforme o art. $60, \S 4^{\circ}$ I e II da CF. ${ }^{40}$

Prevaleceu a constitucionalidade da competência do CNJ da forma como inserida na Lei Maior, por não ferir a autonomia em matéria jurisdicional do magistrado, conforme a decisão do relator César Peluso, ${ }^{41}$ mantendo-se a composição mista e a competência declaradas no art. 103-B da CF.

Embora críticas tenham sido feitas ${ }^{42}$ à criação do CNJ na EC 45/04, a atuação deste órgão externo na reestruturação administrativa judicial e do ministério público tem sido positiva porque tem feito o levantamento da situação da administração da justiça, por meio do controle administrativo e de planejamento financeiro do Poder Judiciário. A racionalização e padronização do serviço judicial por meio de resoluções e portarias, visa a unificar os procedimentos e unificar as práticas administrativas dos ofícios e seções

39 Houve discussão constitucional sobre a nomeação de membro do CNJ fora do Judiciário. Porém permaneceu a composição de um ministro do STF, um do STJ, um do TST, um desembargador de TJ e um juiz estadual, ambos indicados pelo STF, um desembargador federal de TRF e um juiz federal, ambos indicados pelo STJ, um desembargador federal do trabalho de TRT e um juiz do trabalho, ambos indicados pelo TST, um membro do MPU, indicado pelo Procurador-Geral da República, um membro do MPE, escolhido pelo Procurador-Geral da República dentre os indicados pelo órgão competente de cada instituição estadual, dois advogados indicados pelo Conselho Federal da $\mathrm{OAB}$.

40 DINO, Flávio; MELO FILHO, Hugo, BARBOSA, Leonardo A. de Andrade, DINO, Nicolao. Reforma do judiciário, comentários à Emenda n. 45/2004. Rio de Janeiro: Impetus, 2005. prefácio e p. 33-93-114.

41 Id. Tbid., p. 96.

42 Cf. DALLARI, Dalmo de Abreu. O poder dos juizes. São Paulo: Saraiva, 1996. WAMBIER, Teresa Arruda Alvim (Coord.) [et.al]. A reforma do judiciário: primeiros ensaios críticos sobre a EC n. 45/2004. São Paulo: Revista dos Tribunais, 2005. NALINI, José Renato. op.cit. 
dos juízos de primeiro grau e nos tribunais, bem como a responsabilidade funcional dos magistrados. ${ }^{43}$

Entretanto, o planejamento plurianual orçamentário, de levantamento estatístico de dados e movimentação de cartórios, de juízes por habitante, de distribuição de serventuários, uniformização da tecnologia de informatização para racionalizar os procedimentos tem sido relevante como auditoria interna do órgão administrativo do CNJ. Esta finalidade tem como principal escopo levantar as distorções e problemas do Judiciário nos Estados da Federação, a fim de melhorar em âmbito nacional a prestação jurisdicional.

Não se concebe mais o Poder Judiciário de um país diversificado como o Brasil, sem uma análise específica da necessidade de cada Estado Federal, por meio de planejamento em âmbito nacional, e de destinação de orçamento anual para a administração descentralizada dos Tribunais. A soberania e o equilíbrio dos três Poderes do Estado de Direito Democrático somente poderá advir da consolidação administrativa e orçamentária do Judiciário, buscando aprimorara o acesso à justiça, o crescimento homogêneo da distribuição da prestação judicial e qualificação dos recursos humanos. Esta "missão de nortear e planejar o Judiciário, pensar o poder para o futuro" como ressalta em sua obra magistral "A Rebelião da Toga" José Renato Nalini, ${ }^{44}$ nos traz conforto de análise superior do CNJ para a condução do Judiciário brasileiro. Por meio de intervenção e de regulamentação de normas para as práticas judiciais, elaboração de planos plurianuais distintos e orçamentários de crescimentos para cada Tribunal do Estado Federal. O CNJ tem proferido decisões por meio de suas resoluções para unificar os procedimentos e normas a respeito da Magistratura, como exemplo o limite de teto de vencimentos, nepotismo, disciplina das prerrogativas e vedações, procedimento administrativo judicial.

\subsection{Tribunais regionais unificados e descentralizados}

O art. 125 da CF tratou dos Tribunais Estaduais e Juízes na Constituição.

Os Tribunais Estaduais de Alçada Criminal e Civil foram unificados em um único Tribunal de Justiça do Estado, com ampliação da competência para Câmaras Especializadas e aumento do número de membros, com dificuldades para a reorganização interna administrativa e financeira.

Os tribunais de Alçada foram extintos e seus membros passaram a integrar os Tribunais de Justiça dos respectivos Estados, respeitando-se a antiguidade e a classe de origem. Foi inicialmente concedido prazo de 180 dias, a partir da promulgação da EC

\footnotetext{
43 Resolução n. 8 de 7/3/2007, que disciplinou o processo administrativo funcional para os juízes de todos os Tribunais.

${ }^{44}$ NALINI, José Renato. op.cit., p. 11.
} 
45/04 para que os Tribunais de Justiça, por ato administrativo, promovessem a integração em seus quadros dos membros dos tribunais extintos.

Foram instituídas as eleições Internas e Modificação Administrativa da Cúpula e Órgão Especial, conforme reza os arts. 93 e 94 da CF. ${ }^{45}$ In verbis:

A administração judiciária começa pela Cúpula dos Tribunais de Justiça e Federais principalmente com a administração das circunscrições judiciárias estaduais e subseções judiciárias federais. Por isso, a melhor distribuição de recursos financeiros e a destinação às Varas e Cartórios Judiciários são importantes para a o controle judicial de primeira instância e para a agilização dos processos, mais próximo dos jurisdicionados.

As Varas especializadas: agrárias, de meio ambiente, de falências e recuperação judicial de empresas, de consumidor, de família, do setor específico de execuções fiscais também deveriam ser implementadas em primeiro grau, como foram a Vara da Infância e Juventude e Juizados Especiais. Este direcionamento do processo em primeiro grau para juízes e pessoal especializado tem como consequência a agilização do trâmite do processo e de sua execução mais rápida.

$\mathrm{Na}$ Justiça do Trabalho foram criadas dez vagas de juízes de carreira no TST, em substituição aos juízes classistas. A competência da Justiça do Trabalho foi ampliada: ela poderá processar e julgar as ações atinentes ao exercício do direito de greve e de danos morais decorrentes da relação de trabalho (art. 114, I, CF).

Além disso, a mediação e a conciliação são meios para aliviar a carga da Justiça Trabalhista, que cada dia mais aumenta pela disseminação de conflitos laborais e pela gratuidade processual, que permite o ingresso sem qualquer custo ao trabalhador.

A Justiça Militar será competente para o julgamento das ações decorrentes de atos disciplinares militares. Nela, criou-se um juízo monocrático ao se transferir para a competência exclusiva do juiz de direito em atuação na auditoria militar o julgamento dos crimes cometidos contra civis. A presidência formal do Conselho de Justiça foi atribuída ao juiz de Direito naqueles crimes que continuam sendo julgados pelo Conselho.

$45 \quad$ Art. 93 In verbis..[...]:

$\mathrm{X}$ as decisões administrativas dos tribunais serão motivadas e em sessão pública, sendo as disciplinares tomadas pelo voto da maioria absoluta de seus membros; XI nos tribunais com número superior a vinte e cinco julgadores, poderá ser constituído órgão especial, com o mínimo de onze e o máximo de vinte e cinco membros, para o exercício das atribuições administrativas e jurisdicionais delegadas da competência do tribunal pleno, provendo-se metade das vagas por antiguidade e a outra metade por eleição pelo tribunal pleno;

Art. 94. Um quinto dos lugares dos Tribunais Regionais Federais, dos Tribunais dos Estados, e do Distrito Federal e Territórios será composto de membros do Ministério Público, com mais de dez anos de carreira, e de advogados de notório saber jurídico e de reputação ilibada, com mais de dez anos de efetiva atividade profissional, indicados em lista sêxtupla pelos órgãos de representação das respectivas classes.

Parágrafo único. Recebidas as indicações, o tribunal formará lista tríplice, enviando-a ao Poder Executivo, que, nos vinte dias subsequentes, escolherá um de seus integrantes para nomeação. 
Na Justiça Eleitoral permanece a composição do atual texto constitucional, ou seja, dois desembargadores estaduais, dois juízes estaduais, dois advogados e um juiz federal.

A Justiça Eleitoral têm demonstrado a eficiência de recursos mobilizados para as eleições periódicas com agilidade no julgamento de recursos e representações, como forte garantidora do Estado Democrático e sistema político de nosso país, apesar de muitas críticas ${ }^{46} \mathrm{e}$ do aguardo da reforma política.

\subsection{Juizado especial de pequenas causas estadual, federal e da fazenda pública}

De importância na modernização do sistema judicial, os JECs e JEF, civil e criminal, já se estenderam para as Faculdades de Direito, como órgãos de conciliação e mediação, estimulando a disseminação da prática do Direito aos estudantes.

Hoje grande parte da população se utiliza do sistema, cujos princípios de celeridade, oralidade, simplicidade visam à solução do feito em tempo mais apropriado. Porém, o problema ainda persiste na falta de estrutura dos cartórios e juizados especiais, principalmente quanto à execução e concretização da decisão judicial, por meio de nosso sistema de execução concentrado nas mãos do Judiciário.

Na evolução do Judiciário, a celeridade e simplicidade nos JEC e JEF, principalmente pela utilização de oralidade e virtualização dos procedimentos (JEFs), foi importante passo para ampliar o acesso à justiça.

Assim, o art. 98, inciso I e parágrafo primeiro, tem sido cumpridos na consolidação da justiça social.

A regulamentação dos Juizados Especiais Estaduais e Federais a partir da Lei n. 9.099/95 e a Lei n. 10.259 de 12 de julho de 2001, que criou o Juizado Especial Cível e Criminal Federal, propiciou a ampliação do sistema. O JEF já avançado com processo virtual e intimação por via eletrônica com agilização do julgamento dos processos previdenciários e tributários de pequeno valor econômico, com grande avanço na melhoria dos fluxos de processos e eficiência na prestação jurisdicional. ${ }^{47}$

A recente Lei n. 12.153 de 22 de dezembro de 2009 que criou os Juizados Especiais da Fazenda Pública representa grande avanço para a cobrança de valores até 60 salários mínimos (art. $2^{\circ}$ ) para os autores, pessoas físicas, micro empresas e empresas de pequenos portes e requeridos, Entes da administração direta e indireta (art. $5^{\circ}$ ), com a

\footnotetext{
${ }_{46}$ A AMB lançou a lista "negra" dos candidatos inscritos com pendências de processos judiciais e foi muito criticada por esta iniciativa, da qual discordo porque é papel do órgão a informação aos cidadãos sobre os antecedentes dos candidatos, sem tecer juízo algum de valor.

47 Ver comentários sobre a Justiça Especial Federal de Vera Lúcia Feil Ponciano, Juíza Federal da $8^{\mathrm{a}}$ Vara de Curitiba/PR, in $\mathrm{O}$ bom funcionamento do Judiciário como condição para o desenvolvimento econômico in http//www.ibrajus/revista/art?/idartigo $=84$
} 
supressão de prazos diferenciados (art. $7^{\circ}$ ) e com a facilitação da transação em audiência de conciliação, conforme a lei de regência do Ente Federado (art. $8^{\circ}$ ).

Afastado o reexame necessário (art. 11) há grande avança na celeridade e razoável duração do processo judicial, porque retira a morosidade deste privilégio ao Ente Público, que quebra o princípio da igualdade perante a lei.

Houve avanço na execução da decisão transitada em julgado, porque a lei estabelece o prazo de 60 dias, independe de precatório, rompendo com a regra da cobrança por meio demorado de expediente de "oficio precatório" para o pagamento de quantia de pequeno valor do $\S 3^{\circ}$ do art. 100 da CF. Porém, continua a requisição por precatório, se o valor da condenação for superior ao definido por lei como pequeno valor (art. 13, II, $\S 3^{\circ}$ ).

De outra sorte, o legislador perdeu a oportunidade de afastar a cobrança por meio do instrumento de "precatório" que tanto é criticado por promover a procrastinação do cumprimento da decisão judicial, por meio cumprimento de regras rígidas e da "rolagem da dívida" pelo Executivo. Fato este que ainda continua a ser questionado com a recente Emenda Constitucional aprovada para o pagamento de precatórios pelo Congresso (EC 62 de 9 de dezembro de 2009)

As decisões serão revistas pelo Turmas Recursais (art. 17), com a designação de juízes com mandato de 2 anos, com recondução, com a importante ferramenta da “uniformização de interpretação da lei"(art.18) e a súmula “avocatório do julgamento pelo STJ, quando houver interpretação diversa da lei federal das Turmas dos Estados $\left(\S 1^{\circ}\right.$ do art.18), provendo o conteúdo da celeridade processual pela hermenêutica consentânea das Turmas, por via eletrônica de reunião para a sessão de julgamento, por vídeo conferência $\left(\S 2^{\circ}\right.$, art. 18).

Aguarda-se a regulamentação da Lei pelos Tribunais Estaduais e Federais e o prazo de 2 anos para a instalação e provimento dos Juizados Especiais da Fazenda Pública com competência específica nas sessões judiciária e comarcas estaduais, com a melhoria na prestação jurisdicional de causas, no âmbito do Direito Público.

6. Instrumentos alternativos de mediação, conciliação prévia e arbitragem

No tribunal de Justiça de São Paulo foi criado o Setor de Conciliação ou de Mediação nas Comarcas e Foros dos Estados, por meio do Provimento do Conselho Superior da Magistratura n. 953 de 9.08.2005.

Neste setor organizado e específico são feitas as triagens dos processos que são levados primeiramente para a conciliação e mediação, antes de ingressarem e pauta de julgamento, de matéria cível, de família e infância e juventude.

O setor de conciliação do Tribunal de Justiça de São Paulo tem sido ampliado paulatinamente, com a participação de mediadores treinados por cursos específicos, ministrados pela Escola Paulista da Magistratura, para profissionais de outras 
áreas, que não somente de direito para atuarem como conciliadores e mediadores, não remunerados. ${ }^{48}$ Esta prestação de serviço tem como escopo o direcionamento prévio para o setor de conciliação e mediação, criado em primeiro e segundo grau, com eficiente triagem dos processos e para a agilização dos feitos em matéria de Direito disponível e partes privadas.

Há que se ampliar a conciliação para matérias fiscais, com a criação de Leis pelo Executivo para possibilitar a flexibilidade e o acordo, por meio de transação e compensação de serviços a serem prestados tanto por pessoas físicas como jurídicas ao Ente do Estado, como forma de quitação da dívida. Este direcionamento de mediação para o setor público não significa a quebra da exigência da Lei de Responsabilidade Fiscal de cobrança de impostos, mas de inovação na arrecadação de dívida ativa, com a possibilidade de alívio da carga de processos judiciais, enviados ao setor de execução fiscal, que hoje transformou-se em "cobrador de impostos" do Poder Executivo.

A arbitragem criada pela Lei n. 9.307/1996 no Brasil ainda não foi utilizada na prática a contratos particulares e consumidores, como pessoas físicas e pequenas e médias empresas, pois somente as multinacionais se utilizam dos instrumentos normativos da arbitragem. Isso não significa que não possam ser os preceitos da lei de arbitragem (como flexibilidade de leis aplicadas, escolha da equidade no julgamento, escolha de árbitros ou "juízes de aluguel") aplicados a contratos por cláusula compromissória ou compromisso arbitral, desde que o direito seja disponível e partes privadas.

Já existem vários órgãos privados denominados Tribunais Arbitrais para dirimir conflitos de natureza privada e disponíveis, principalmente com a aplicação em contratos de empresas e consumidores.

Os órgãos da administração pública, desde que criem leis específicas (Princípio da Legalidade), poderão se valer da mediação e conciliação e até da arbitragem para resolver seus conflitos de pequena monta, (art. $37, \S 6^{\circ} . \mathrm{CF}$ ), pois o Direito é disponível e a responsabilidade é objetiva pelo risco administrativo e pela falha ou falta na prestação de serviço público, como por exemplo queda em buracos públicos por falha na execução de asfaltamento, queda de árvores, falta de sinalização suficiente em ruas e calçamentos.

\section{Eficiência é paradigma para o poder judiciário}

A sociedade na era do neoliberalismo e pospositivismo ${ }^{49}$ da evolução rápida de informações está cada vez mais exigindo a contrapartida de eficiência na gestão do Poder

\footnotetext{
48 LAGRASTA, Valéria Ferrioli. O gerenciamento de casos. In: FREITAS, Vladimir Passos; ALMEIDA, Dario Passos de (Coord.). Direito e administração da justiça. Curitiba: Ed. Juruá, 2006, p. 204.

49 CAlHAO, Antonio Ernani Pedroso. Presteza jurisdicional como paradigma da Administração Judiciária.2009. Tese (Doutorado) - Pontifícia Universidade Católica, São Paulo. p. 257
} 
Judiciário, porque cobra mudança da mentalidade hermética e formal, com a necessária integração social pró-ativa, flexível e mais dinâmica para acompanhar a evolução e instabilidade, enfrentada pela sociedade disforme e globalizada. As Constituições modernas imprimiram ao Poder Judiciário uma força por meio de princípios e normas objetivos, que precisam ser preenchidas pela intérprete judicial, para as mudanças exigidas pelo ordenamento social.

Instrumentos processuais modernos, a dinâmica dos princípios da razoabilidade, discricionariedade, celeridade e eficiência processual da Constituição Federal de 1998, somados aos meios de tecnologia de informação e meios alternativos de solução de conflitos proporcionam a base para a mudança de mentalidade do magistrado e do operador do direito.

A racionalização dos procedimentos e normas de administração judicial por meio da intervenção e direcionamento do CNJ e a racionalização e pacificação da jurisprudência dos Tribunais Superiores, por meio de efeitos vinculantes de súmulas e da limitação de recursos protelatórios pela decisão emanada da repercussão geral de matérias semelhantes á julgadas em definitivo. ${ }^{50}$

A mudança de paradigma depende de treinamento e qualificação dos serventuários da justiça com a criação de quadro de carreira unificado, criação de cargos específicos de administradores judiciais, gerentes de informática e de gestão dos ofícios e seções, para aperfeiçoar a prestação de serviços judiciais.

Para agentes públicos dos quadros da Magistratura, Ministério Público e da Advocacia Pública cabe o aprimoramento por cursos de administração judiciária em Escolas Superiores do Tribunal ou Órgãos, que estimulem o aperfeiçoamento de técnicas em informatização, liderança, motivação de pessoal e gestão e controle de serviço público.

O treinamento do estudante de direito e de administração por meio de cursos voltados à administração Judiciária, como exemplo do curso pioneiro de Especialização em Política Judiciária e Administração da Justiça da PUCPR. ${ }^{5 !}$ É necessário treinamento técnico para formar um profissional mais consciente e talhado para assumir as funções de liderança da administração judiciária em tempos modificação de postura e mentalidade do operador de direito moderno.

Ademais, é importante a atualização do Direito por meio de interpretação e aplicação constante dos princípios constitucionais para dinâmica do julgamento ser conforme à Constituição (Princípio da Razoabilidade/Racionalidade) e princípios informadores do Direito processual constitucional moderno, conforme explicita Luis

so FUX, Luiz, Súmula Vinculante e Repercussão Geral para o STJ. Disponivel em: <http://www.migalhas. com. br>. Acesso em: 16 jan. 2009

51 Conf. FREITAS, Vladimir Passos; ALMEIDA, Dario Passos de (Coord.). Direito e administração da justiça. Curitiba: Juruá, 2006. 
Roberto Barroso: "o ponto de partida do intérprete há que ser sempre os princípios constitucionais, que são o conjunto de normas que espelham a ideologia da Constituição, seus postulados básico e seus fins" 52

Outro ponto de importância para a modernização é a busca de aprimoramento da tecnologia de informação para o aprimoramento e racionalização em âmbito nacional do controle das seções e procedimentos administrativos internos dos Tribunais.

Mais uma vez a importância de administradores judiciais, lotados nos Tribunais, nos Fóruns e Seções Judiciárias (Estadual e Federal), com nomeação por concurso público, com atuação na área administrativo-econômica, os quais planejam em conjunto com as comissões do Tribunal e do CNJ, por auditorias, estatísticas e gestão de orçamento anual a ser destinado ao aperfeiçoamento da gestão de serviço público.

Além de tudo isso, a aplicação dos procedimentos virtuais facilitará em muito a padronização e racionalização dos serviços a serem prestados aos "consumidores da justiça" pelos tribunais, com eficiência e celeridade, permitindo mudança e adaptações mais flexíveis ao tempo do procedimento.

Por fim, o trabalho incessante e dinâmico desenvolvido pelas Associações de Classes para aproximação entre o Judiciário e os Poderes Legislativo e Executivo.

A construção de relacionamento com os dois outros poderes por meio de técnica efetiva de aproximação de interesses (formação de lobby de defesa de interesse no Congresso), modificação da legislação complementar e ordinária, que vem sendo utilizado nos Judiciários Europeus, ${ }^{53}$ para defesa da independência de gestão de orçamento público, destinado à melhoria e eficiência da prestação de serviço judicial.

\section{Conclusão}

A reforma do Poder Judiciário introduziu o princípio da celeridade e razoável duração do processo (art. 5, LXXVIII da CF) tem sido debatida por todos os operadores do Direito, por ser inerente o poder ao Estado de Direito Democrático, no qual vivemos.

O início desta "reforma" foi tecida no âmbito político-parlamentar por mais de 12 anos e foi motivada pela forma de atuação do Poder Judiciário na sociedade da pós-modernidade, com exigências de controle e de eficiência da prestação de serviços públicos.

AEC 45/04 foi um importante início das modificações judiciais institucionais, estruturais e procedimentais. Porém, não mostrou ser suficiente para amenizar o problema

52 BARROSO, Luís Roberto. Interpretação e aplicação da Constituição: fundamentos de uma dogmática constitucional transformadora. 6. ed. rev. atual. e ampl. São Paulo: Saraiva, 2004. p. 151

53 BELL, John. Judiciaries within Europe. A Comparative Review. United Kingdom: Cambridge University Press, 2006. 
do acesso à justiça e do volume excessivo de demanda judicial e da falta de estrutura material e de recursos humanos, enfrentada pela dependência orçamentária do Poder Judiciário do Poder Executivo.

Princípios constitucionais de eficiência, celeridade e instrumentalidade de meios para a eficácia da prestação judicial foram introduzidos e devem ser regulamentados e interpretados por todos aqueles que acreditam na melhoria do serviço.

A Superposição do STF como corte constitucional deve ser repensada para liberar a função primordial de Corte de Cassação, com o dever de judicial review, como a Suprema Corte Americana, e as Cortes Européias.

Por isso, ressalta-se a importância da racionalização de recursos que levam toda a matéria para o STF, controlada por Súmulas Vinculantes e Súmulas de Repercussão Geral e Obstativas de Recursos.

Os Tribunais Superiores e Conselho Nacional de Justiça têm importante papel na reestruturação da Jurisprudência e na normatização de práticas judiciais, direcionamento da jurisprudência dominante e colheita de dados e estatísticas anuais para a gestão da administração judiciária em nível nacional.

Os meios alternativos de solução de conflitos, com alívio da demanda, os Juizados Especiais, para dar oportunidade ao acesso à justiça e as varas Especializadas para a racionalização de julgamento de processos são meios importantes para a agilização e eficiência do Judiciário, aproximando-o da população.

Enfim, o magistrado não pode se olvidar que tem hoje uma missão de baluarte da justiça. $\mathrm{O}$ aperfeiçoamento na área administrativa constitui ferramenta importante para melhoria da prestação jurisdicional, cumprindo com o princípio da razoável duração do processo no cartório. A informatização e a gestão administrativa de recursos humanos propiciará a celeridade que se pretende, com o tempo de cumprimento dos atos e decisões mais eficaz, em favor da parte e não contra esta, como no texto intitulado de Joaquim Falcão, "a pena é o processo"(Folha de S.Paulo, Opinião A3 terça-feira, 8.06.2010).

O princípio da eficiência judicial não deve uma simples "norma-objetivo", mas sim um "novo paradigma do acesso à Justiça", para que todos os operadores do direito possam buscar a efetiva justiça, que é a virtude mais alta de todas, na filosófica aristotélica.

São Paulo, setembro de 2010.

\section{Referências}

ALMEIDA, Jorge Luiz (Coord.). Emenda constitucional n. 45/04 e responsabilidade. In: A REFORMA do Poder Judiciário. Campinas: Millennium, 2006.

BARROSO, Luís Roberto. Interpretação e aplicação da Constituição: fundamentos de uma dogmática constitucional transformadora. 6. ed. rev. atual. e ampl. São Paulo: Saraiva, 2004. 
BARTOLETTI, Fernando Figueiredo. Regime de aposentadoria e de pensão para agentes públicos da magistratura e seus dependentes, EC n. 18/98, 41/03 e 47/05. Disponível em: <http://www. apamagis.com.br> Acesso em: 4 nov. 2008.

BENUCCI, Renato Luís. A tecnologia aplicada ao processo judicial. Campinas: Millennium, 2007.

BEZERRA, Márcia Fernandes. O direito à razoável duração do processo e a responsabilidade do Estado pela demora na outorga da prestação jurisdicional. In: WAMBIER, Teresa Arruda Alvim et al. (Coord.). Reforma do judiciário: primeiros ensaios críticos sobre a EC n. 45/2004. São Paulo: Revista dos Tribunais, 2005. p. 467-479.

CALHAO, Antonio Ernani Pedroso. A prestação jurisidicional como paradigma da prestação Judiciário. 2009. Tese (Doutorado) - Pontifícia Universidade Católica, São Paulo.

CLÉVE, Clémerson Merlin. Breves comentários sobre os 20 anos da Constituição Federal. <http:// www.migalhas.com.br>. Acesso em: 6 out. 2008.

COSTA, Marcos da; MARCACINI, Augusto Tavares Rosa. Direito em bits. São Paulo: Fiúza, 2004. FRANCIULLI NETO, Domingos. A prestação jurisdicional, o ideal idealíssimo, o ideal e o processo de resultados. Campinas: Millennium, 2004.

DELGADO, José Augusto. Reforma do poder judiciário: art. 5 LXXVIII, da CF. In: WAMBIER, Teresa Arruda Alvim et al. (Coord.). Reforma do judiciário: primeiros ensaios críticos sobre a EC n. 45/2004. São Paulo: Revista dos Tribunais, 2005. p. 355-371.

DINO, Flávio et al. Reforma do judiciário: comentários à Emenda n. 45/2004. Niterói: Impetus, 2005. p. 96-114.

HIEN, Eckart. A reforma do sistema judicial alemão. Revista CEJ, Brasília, v. 10, n. 34, p. 52-55, jul./set. 2006.

HOFFMAN, Paulo. O direito à razoável duração do processo e a experiência italiana. In: WAMBIER, Teresa Arruda Alvim et al. (Coord.). Reforma do judiciário: primeiros ensaios críticos sobre a EC n. 45/2004. São Paulo: Revista dos Tribunais, 2005. p. 521-589.

KOERNER, Andrei. Judiciário e cidadania na Constituição da República brasileira. São Paulo: HUCITEC, Departamento de Ciência Política da USP, 1998.

LAMY, Eduardo. Súmula vinculante: um desafio. Revista de Processo, São Paulo, v. 30, n. 120, p. 112-137, fev. 2005.

LIMONGE, Celso Luiz; STEFANO, Cláudia. Breves anotações sobre a reforma do judiciário. In: ALMEIDA, Jorge Luiz de (Coord.). A reforma do judiciário, uma abordagem sobre a Emenda Constitucional 45/2004. São Paulo: Millennium, 2007.

MANCUSO, Rodolfo de Camargo. Súmula vinculante e a EC n. 45/2004. In: WAMBIER, Teresa Arruda Alvim et al. (Coord.). Reforma do judiciário: primeiros ensaios críticos sobre a EC n. 45/2004. São Paulo: Revista dos Tribunais, 2005. p. 685-719. 
MEDEIROS, Maria Lúcia L. C. de. O inciso XIV do art. 93 da CF. In: WAMBIER, Teresa Arruda Alvim et al. (Coord.). Reforma do judiciário: primeiros ensaios críticos sobre a EC n. 45/2004. São Paulo: Revista dos Tribunais, 2005. p. 487-492.

MEDINA, José Miguel Garcia; WAMBIER, Luiz Rodrigues; WAMBIER, Teresa Arruda Alvim. Repercussão geral e súmula vinculante: relevantes novidades trazidas pela EC n. 45/2004. In: WAMBIER, Teresa Arruda Alvim et al. (Coord.). Reforma do judiciário: primeiros ensaios críticos sobre a EC n. 45/2004. São Paulo: Revista dos Tribunais, 2005. p. 373-389.

MENDES, Gilmar Ferreira. Arguição de descumprimento de preceito fundamental: comentários à Lei n. 9.882, de 3-12-1999. São Paulo: Saraiva, 2007. p. 149-157 e 186-210.

MORATO, Leonardo Lins. A reclamação e a sua finalidade para impor o respeito à sumula vinculante. In: WAMBIER, Teresa Arruda Alvim et al. (Coord.). Reforma do judiciário: primeiros ensaios críticos sobre a EC n. 45/2004. São Paulo: Revista dos Tribunais, 2005. p. 391-413.

NALINI, José Renato. A rebelião da Toga. 2. ed. Campinas: Millennium, 2008.

OLIVEIRA, Robson Carlos de. O princípio constitucional da razoável duração do processo, explicitado pela EC n. 45, de 08.12.2004, e sua aplicação à execução civil: necessidade de que o Poder Judiciário através dessa norma princípio flexibiliza as regras jurídicas e passe a aplicálas, garantindo um efetivo e qualificado acesso à Justiça. In: WAMBIER, Teresa Arruda Alvim et al. (Coord.). Reforma do judiciário: primeiros ensaios críticos sobre a EC n. 45/2004. São Paulo: Revista dos Tribunais, 2005. p. 655-684.

OSÓRIO, Fábio Medina. O "novo" sistema judicial brasileiro: significados e significantes. In: OSÓRIO, Fábio Medina; SOUTO, Marcos Juruena Villela (Coord.). Direito administrativo: estudos em homenagem a Diogo de Figueiredo Moreira Neto. Rio de Janeiro: Lumen Júris, 2006. p. 59-107.

PASSOS, J. J. Calmon de. Reforma do poder judiciário. Revista Brasileira de Ciências Criminais, v. 16, n. 71 , p. 344-363, mar./abr. 2008.

SAADI, Bernardo de Vilhena. A constitucionalidade da súmula vinculante. Revista de Direito Administrativo, São Paulo, n. 244, p. 13-52, jan./abr. 2007.

SADEK, Maria Tereza, (Org.): Reforma do judiciário. São Paulo: Fundação Konrad Adenauer, 2001. 